1.01

Igor Ivašković*

\title{
Pravna narava Države in Kraljestva/ Kraljevine SHS v konfliktu jugoslovanskih ideologij
}

\section{IZVLEČEK}

Glavna teza prispevka je, da razlike v razlagi pravne narave Države Slovencev, Hrvatov in Srbov ter tudi Kraljestva/Kraljevine Srbov, Hrvatov in Slovencev niso bile posledica pravne negotovosti, temveč so bile le odraz še ene izmed mnogih političnih bitk $v$ vojni nasprotujočih si jugoslovanskih ideologij. Avtor uporablja mednarodna in ustavna merila ter analizira dileme glede pravne narave države SHS in pravne (dis) kontinuitete med Kraljevino Srbijo in Kraljestvom/Kraljevino SHS. Na temelju analize argumentira, da: 1) je Država SHS izpolnjevala temeljne kriterije državnosti in jo lahko imamo za državo ter 2) da je bilo Kraljestvo/Kraljevina SHS nova država, saj ni bila ustvarjena v skladu s standardi prejšnje srbske ustave; ravno nasprotno, Kraljestvo SHS je prekinilo ustavno kontinuiteto Kraljevine Srbije.

Ključne besede: Država SHS, Kraljevina SHS, Kraljevina Srbija, jugoslovanske ideologije, ustava

\section{ABSTRACT}

\section{THE LEGAL NATURE OF THE STATE AND THE KINGDOM OF SHS IN THE CONTEXT OF THE CONFLICTING YUGOSLAV IDEOLOGIES}

The main thesis of the article is that the differences in the interpretations of the legal natures of the State of Slovenes, Croats and Serbs and the Kingdom of Serbs, Croats and Slovenes were not the consequence of legal uncertainty, but rather reflected yet another

* Dr., docent, Ekonomska fakulteta Univerze v Ljubljani, Kardeljeva ploščad 17, SI-1000 Ljubljana; igor.ivaskovic@ef.uni-lj.si 
among the many political battles in the conflict between the opposing Yugoslav ideologies. The author uses the international and constitutional criteria to analyse the dilemmas regarding the legal nature of the State of SHS and the legal (dis)continuity between the Kingdom of Serbia and the Kingdom of SHS. He argues that: 1) the State of SHS satisfied the fundamental requirements to be considered as a state; and 2) the Kingdom of SHS was a new state, as it was not created according to the standards of the Serbian Constitution. Moreover, it suspended the constitutional continuity of the Kingdom of Serbia.

Keywords: State of SHS, Kingdom of SHS; Kingdom of Serbia; Yugoslav ideologies; constitution

\section{Uvod - kontekst konca prve svetovne vojne}

Vizije južnoslovanske države pred prvo svetovno vojno so si bile v paradigmatskem nasprotju. Del Slovencev in Hrvatov je velike upe polagal v ohranitev habsburške države in ustanovitev južnoslovanske enote, ki bi bila enakopravna avstrijskemu in ogrskemu delu monarhije, na drugi strani pa je politični vrh Srbije ravno habsburško monarhijo videl kot glavno oviro na poti do uresničenja svoje vizije južnoslovanske države. Posledično je vodil politiko priključevanja habsburških južnih Slovanov, ne pa njihovega združevanja. ${ }^{1}$ Različne vizije prihodnosti so se odražale tudi v pravnopolitičnih aktih, ki so jih različne strani objavljale v obdobju prve svetovne vojne. $\mathrm{Na}$ eni strani sta glavna elementa Majniške deklaracije bila habsburški državni okvir, ki ga nekateri zgodovinarji sicer razumejo le kot taktično ali neiskreno klavzulo, ${ }^{2}$ in hrvaško historično državno pravo. Na drugi strani pa se je kot predpogoj južnoslovanske skupnosti izpostavljala srbska kraljevska dinastija Karađorđević.

Na udejanjenje južnoslovanske države je bistveno vplival rezultat prve svetovne vojne, ki je porušil dotedanja razmerja v širši mednarodni skupnosti. Čeprav zgodovinopisna dela, ki so v specifičnem kontekstu nastala med dvema svetovnima vojnama pri Slovencih, ${ }^{3}$ poskušajo prikazati drugačno sliko, je šele v obdobju vojne tudi med Slovenci prevladala usmeritev, da se slovensko vprašanje v kontekstu južnoslovanske enote reši zunaj, in ne znotraj habsburške monarhije. ${ }^{4}$ Porazi avstro-ogrske vojske in posledično sesedanje habsburške monarhije od znotraj ter nepripravljenost dunajskih, še manj pa madžarskih političnih elit na popuščanje slovenskim in hrvaškim željam po politični emancipaciji, ${ }^{5}$ obenem pa mednarodne okoliščine in informacija,

1 Ferdo Čulinović, Tri etape nacionalnog pitanja u jugoslovenskim zemljama (Zagreb: Jugoslavenska akademija znanosti i umjetnosti, 1962), 24, 25.

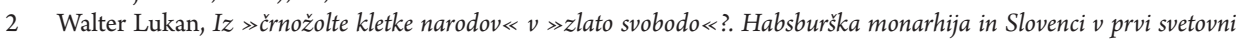
vojni (Ljubljana: Znanstvena založba Filozofske fakultete Univerze v Ljubljani, 2014), 85.

3 Npr. Jože Lavrič, Josip Mal in France Stele, ur., Spominski zbornik Slovenije (Ljubljana: Jubilej, 1939).

4 Jurij Perovšek, Slovenska osamosvojitev v letu 1918 (Ljubljana: Modrijan, 1998), 13.

5 Vlasta Stavbar, Majniška deklaracija in deklaracijsko gibanje (Maribor: Založba Pivec, 2017), 55-60. 
da bodo antantne sile vendarle sprejele razbitje Avstro-Ogrske, ${ }^{6}$ so 29. oktobra 1918 njihove politične predstavnike spodbudili $\mathrm{k}$ prekinitvi vseh državnih zvez z dualistično monarhijo. ${ }^{7} \mathrm{Na}$ celotnem južnoslovanskem področju nekdanje Avstro-Ogrske je oblast prevzel nov izvršni organ Narodni svet (Vijeće) Slovencev, Hrvatov in Srbov v Zagrebu (v nadaljevanju besedila 'zagrebški Narodni svet'), s čimer se je formirala Država Slovencev, Hrvatov in Srbov (Država SHS). S tem so na hrvaških in tudi na slovenskih področjih prehiteli posamezne poskuse ustanavljanja sovjetskih republik po boljševističnem vzoru. ${ }^{8} \mathrm{Na}$ člane Narodnega sveta so pritiskale zunanje okoliščine, predvsem zmagovalci vojne, ki si niso želeli privoščiti oblikovanja držav brez lastnega nadzora. Pri tem je prednjačila Velika Britanija, ki se je že v okviru Londonskega pakta leta 1915 obvezala Italiji in Srbiji. Ni presenetljivo, da sta ravno britanska in francoska diplomacija spodbudili pogovore med predstavniki Države SHS in Nikolo Pašićem, predsednikom vlade Kraljevine Srbije. Sledila so kratka pogajanja in 9. novembra 1918 podpis Ženevske deklaracije, ki je določala ustanovitev skupne jugoslovanske države in pooblaščanje bodoče ustavodajne skupščine za odločanje o temeljnih vprašanjih ureditve nove države. $S$ podpisom sporazuma, ki je predvideval federativno osnovo združitve Države SHS in Kraljevine Srbije, srbska vlada ni le priznala legitimnosti Narodnemu svetu kot predstavniku Države SHS, temveč je to pomenilo tudi priznanje enakopravnosti dveh državnih subjektov. ${ }^{9}$ Ne nazadnje je to potrdil tudi sam Pašić v izjavi pred ženevsko konferenco, 25. oktobra 1918: »Srbi ne želimo v bodoči kraljevini SHS zavzeti hegemonističnega stališča. Slovesno izjavljam, da smatra Srbija za svojo nacionalno dolžnost osvoboditi Srbe, Hrvate in Slovence. Osvobojeni bodo imel pravico do samoodločbe, upravičeni bodo imeli pravico, da se izjasnijo, ali se hočejo pridružiti Srbiji v smislu krfske deklaracije ali pa hočejo ustanoviti samostojne države. $\mathrm{Ne}$ dopuščamo, da bi se kakorkoli omejila pravica samoodločbe Hrvatom in Slovencem. Tudi na krfski deklaraciji ne bomo vztrajali, ako ne ustreza njihovim željam. ${ }^{10}$

Ta izjava je odražala duh trenutka in poveličevanje načela samoodločbe narodov, ki ga je zmagovalna antantna koalicija vsaj deklarativno prikazovala kot najpomembnejši prispevek k mednarodnim odnosom in mednarodnemu pravu. Pašić tega v svojih izjavah ni smel ignorirati, intimno pa se je zavedal boljšega izhodiščnega položaja Srbije v primerjavi s Slovenci in Hrvati. Slednjim je tako prepuščal le privid možnosti svobodnega odločanja med skupno državo s Srbi in samostojnimi državami. Potencialni samostojni državi ali skupna država Slovencev in Hrvatov namreč po srbskem mnenju nikakor ne bi mogla vključevati tistih področij, ki so jih v večji meri poseljevali Srbi. Hrvaška tako praktično ne bi mogla obstati kot samostojen mednarodni subjekt,

6 Janko Pleterski, Prva odločitev Slovencev za Jugoslavijo (Ljubljana: Slovenska matica, 1971), 202.

7 Jurij Perovšek, Slovenski prevrat 1918. Položaj Slovencev v Državi Slovencev, Hrvatov in Srbov (Ljubljana: Inštitut za novejšo zgodovino, 2018), 77-79.

8 Ivo Banac, »Emperor Karl Has Become a Comitadji: The Croatian Disturbances of Autumn 1918, « The Slavonic and East European Review 70, št. 2 (1992): 301.

9 Jurij Perovšek, »Jugoslovanska združitev, « v: Slovenska novejša zgodovina. Od programa Zedinjena Slovenija do mednarodnega priznanja Republike Slovenije: 1848-1992, ur. Jasna Fisher et al. (Ljubljana: Mladinska knjiga in Inštitut za novejšo zgodovino, 2005), 200, 201.

10 Albin Prepeluh, Pripombe k naši prevratni dobi (Trst: Založništvo tržaškega tiska, 1987), 130, 131. 
enako pa je zaradi italijanskih teritorialnih ambicij veljalo tudi za slovenska področja. Če upoštevamo te okoliščine, je bil sporazum iz Ženeve precejšen politični dosežek Anteja Trumbića in Antona Korošca, ki jima je skupaj s srbsko opozicijo uspelo pripraviti Pašića do privolitve v zahtevo o ureditvi, ki bi bila podobna nekakšni novi dvojni monarhiji. ${ }^{11}$ Sporazum je namreč vseboval federalne in konfederalne elemente, na katerih naj bi bodoča ustavodajna skupščina utemeljevala svoje delo. Bodočo državo bi po slednjem vodila vlada z 12 člani, pri čemer bi polovico ministrov imenovala srbska vlada in bi prisegli srbskemu kralju, medtem ko bi drugi del vlade predložil zagrebški Narodni svet, njegovemu predsedniku pa bi priseglo drugih šest ministrov. ${ }^{12}$ Ženevska deklaracija je torej v nasprotju s sporazumom na Krfu odrekala vnaprejšnje prepuščanje oblasti Karađorđevićem na celotnem območju, saj bi Narodni svet vsaj do sprejetja ustave opravljal posle, ki so se nanašali na celotno ozemlje Države SHS. Ravno to je bil glavni razlog, zakaj srbska vlada sporazuma ni potrdila. ${ }^{13}$

\section{Pravnopolitične nejasnosti združitvenega akta}

Srbiji se je še pred odločitvijo o združitvi Države SHS s Kraljevino Srbijo že priključila Vojvodina, in sicer 25. novembra 1918. Država SHS na tem področju ni imela pomembnejšega vpliva, v pokrajini pa se je konec vojne že nakopičila srbska vojska. Le dan pozneje sta bili v Črni gori zrušena oblast kralja Petrovića in razglašena združitev s Srbijo. Na Hrvaškem sta se v tem obdobju istočasno oblikovali dve struji, kar se je odražalo tudi v Narodnem svetu. Na eni strani je del članov skupaj z Jugoslovanskim odborom poskušal doseči mednarodno priznanje Države SHS, medtem ko so si predvsem predstavniki hrvaških Srbov pod vodstvom Svetozarja Pribićevića želeli čimprejšnje združitve s Srbijo, po možnosti brez predhodnega mednarodnega priznanja Države SHS. Temu se je najbolj uprl Stjepan Radić, za katerim so ostali zabeleženi številni govori nasprotovanja takojšnji združitvi s Srbijo, med najbolj znamenitimi pa je bil ravno sledeči: »Gospodje! Ni še prepozno! Ne rinite kot gosi v meglo! Ne sklepajte enotne vlade s Kraljevino Srbijo že zato, ker, kot vidite, v imenu Kraljevine Srbije ni tu nikogar, ničesar, razen ene brzojavke, pa tudi ta predstavlja nekaj drugega kot vi. Ne ravnajte tako, da se bo danes-jutri že lahko govorilo, da ste tudi vi Slovenci in vi Srbi Vojvodinci in Bosanci in vi Hrvati Dalmatinci, predvsem pa vi naši domači hrvaški Srbi, da ste se vsi zbrali danes tu samo zato, da izvršite zaroten čin proti narodu, predvsem proti Hrvaški in Hrvatom. ${ }^{14}$

11 John R. Lampe, Yugoslavia as History. Twice There Was a Country. Second edition (Cambridge: Cambridge University press, 2002), 111.

12 Andrej Rahten, Slovenska ljudska stranka $v$ beograjski skupščini. Jugoslovanski klub v parlamentarnem življenju Kraljevine SHS 1919-1929 (Ljubljana: Založba ZRC, 2002), 26.

13 Neda Engelsfeld, Povijest hrvatske države i prava - razdoblje od 18. do 20. stoljeća (Zagreb: Pravni fakultet, 2002), 277. Perovšek, Jugoslovanska združitev, 201.

14 Stjepan Radić, Politički spisi. Autobiografija, članci, govori, rasprave (Zagreb: Znanje, 1971), 334. 
Radić je v kontekstu kopice različnih alternativnih državnopravnih ureditev predlagal ustvarjanje hrvaške republike po vzoru ZDA, ta naj bi temeljila na hrvaškem državnem pravu in načelu samoopredelitve. Iskanje državnih alternativ je slonelo na temeljni predpostavki, da z združevanjem s Srbijo ni treba hiteti, temveč se mora Država SHS čim bolj pripraviti na odnose s svojo sosedo, ki je bila v veliko boljšem izhodiščnem položaju. Slednje bi ob morebitni združitvi impliciralo nevarnost centralistične in unitaristične ureditve, v kateri bi ostali južnoslovanski narodi bili le $\gg$ privesek« k Srbiji. Radić je v hrvaški skupščini (sabor) nadaljeval: »Gospodje! Polna usta besed imate: narodna enotnost - enotna država, eno kraljestvo pod dinastijo Karađorđevićev. In vsi mislite, da je to dovolj, govoriti, da smo mi Hrvati, Srbi in Slovenci en narod, zato ker govorimo en jezik, pa da moramo zato imeti centralistično državo, in to kraljestvo, in da nas samo to, takšna jezikovna in državna enotnost pod dinastijo Karađorđevićev, lahko reši in osreči ... Vi, torej, naš narod ustrahujete kot majhne otroke in mislite, da boste tako narod pridobili za svojo politiko. Mogoče boste Slovence, ne vem; mogoče boste za trenutek pridobili tudi Srbe; ampak vem, da Hrvatov za to ne boste pridobili, ne boste pa jih pridobili zato, ker je ves hrvaški kmečki narod ravno tako proti vašemu centralizmu, kot je proti militarizmu, ravno tako za republiko kot tudi za narodni sporazum s Srbi. In če boste vi hoteli s silo vsiliti svoj centralizem, se bo zgodilo tole. Mi Hrvati bomo rekli odprto, čisto in bistro: Ej, če Srbi zares hočejo imeti takšno centralistično državo in vlado, bog naj jim jo blagoslovi; ampak mi Hrvati nočemo druge ureditve kot zvezno federativno republiko. $\ll{ }^{15}$

Radić je zato pred združitvijo predlagal, naj novo državo začasno vodijo trije regenti - srbski prestolonaslednik, hrvaški ban in predsednik slovenskega narodnega sveta. Konstituanta bi po tem načrtu bila sestavljena iz 42 članov; po deset od teh bi jih določili srbska in hrvaška skupščina ter Narodni svet za Slovenijo in Istro v Ljubljani, bosanski sabor bi imel pravico do izbora štirih članov, črnogorska skupščina, dalmatinski deželni zbor, predstavniki Vojvodine in predstavniki Istre pa vsak po dva člana. ${ }^{16}$ Vendar tudi dobro poznavanje razmer v Srbiji Radiću ni pomagalo pri pridobitvi širše podpore ostalih poslancev, le skupina socialistov je bila naklonjena začasnemu tričlanskemu regentstvu v novi državi.

Konec novembra 1918 se je zdelo, da je Radićeva ideja popolnoma poražena na račun uresničitve vizije Hrvaško-srbske koalicije, ki je zastopala idejo čimprejšnje združitve s Srbijo. Pri tem je bilo vsekakor zanimivo dejstvo, da so tudi mnogi hrvaški politiki v tej politični skupini poudarjali argument, da morata Država SHS in Kraljevina Srbija prevzeti vlogi v skladu s statusom poraženca in zmagovalca v vojni, kar je impliciralo neenakopravnost teh dveh subjektov znotraj bodoče države. Primer tega je bil Drinkovićev govor: Mi ne ustanavljamo niti Velike Srbije, niti Velike Hrvaške, niti Velike Slovenije, ampak veliko, močno jugoslovansko državo. Moramo pa kljub temu glasno priznati, da je srbska kraljevina iz te vojne prišla kot zmagovalka, mi (Hrvati) pa

15 Ivo Banac, Nacionalno pitanje u Jugoslaviji. Porijeklo, povijest, politika (Zagreb: Globus, 1988), 216.

16 Prepeluh, Pripombe, 171-75. 
smo premagani. Razum in poštenje nalaga vsakemu patriotu, da v teh velikih trenutkih vstane za narodno in državno enotnost. ${ }^{17}$

Odbor zagrebškega Narodnega sveta je naposled določil 28-člansko delegacijo, ki je dobila nalogo izvršitve odločitve o združitvi. Tej skupini so bila dana tudi posebna navodila, med katerimi je izstopala določba, da končno obliko organizacije države določi konstituanta $\mathrm{z}$ dvotretjinsko večino. Vendar ti napotki po prihodu delegacije v Beograd niso odigrali nikakršne vloge. Srbska diplomacija je obenem spretno onemogočila povratek Antona Korošca in Anteja Trumbića iz Ženeve, s čimer je vlogo najpomembnejšega akterja Države SHS prevzel Svetozar Pribićević. Slednji je predstavljal srbsko stran v vodstvu Države SHS in so ga s hrvaškega stališča, kljub svoji zelo kompleksni in kontroverzni politični karieri ter dinamičnem odnosu z Zagrebom in Beogradom, pogosto poenostavljeno zaznavali kot velikosrbski element znotraj Hrvaške. Dejstvo je, da je v tistem obdobju deloval v prid uresničevanja hegemonistične politike iz Beograda, pod njegovim vplivom pa je Ante Pavelić (zobozdravnik) 1. decembra 1918 prebral le splošno izjavo, s katero je predal oblast prestolonasledniku Aleksandru Karađorđeviću, ki je razglasil združitev Srbije in Države SHS (oz. ozemelj, ki jih je predstavljal zagrebški Narodni svet) ter nastanek Kraljestva Srbov, Hrvatov in Slovencev (Kraljestvo SHS). Sporazum so praktično v celoti sestavili predstavniki Kraljevine Srbije in je omogočal začasno centralistično ureditev $\mathrm{z}$ dominacijo najštevilnejšega naroda. V prvi vladi je bilo tako izmed 20 ministrov 13 Srbov, štirje Hrvatje, dva Slovenca in en bosanskohercegovski musliman. ${ }^{18}$ Združitveni akt ni povzročil nezadovoljstva le pri nasprotnikih centralizma in srbske hegemonije, temveč je sprožil tudi celo kopico pravnih vprašanj in nesoglasij med zagovorniki različnih jugoslovanskih konceptov.

Konflikt južnoslovanskih ideologij se je po združitvi prenesel na pojasnjevanje učinka prvodecembrskega akta. Sprva je bil ta pri hrvaški in slovenski politični eliti sicer sprejet z odobravanjem. Osrednji odbor iz Zagreba je samo dva dni po tem objavil, da je prenehal opravljati funkcijo vrhovne in suverene oblasti Države SHS ter da od 1. decembra tvori naš celokupni narod slovensko-hrvaško-srbsko državo pod regentstvom Njegovega kraljevskega Visočanstva prestolonaslednika Aleksandra. ${ }^{19}$ Tudi Narodna vlada SHS v Ljubljani, ${ }^{20}$ pooblaščena za upravljanje slovenskih področij ${ }^{21}$ v Državi SHS, je v sporočilu kralju Petru in regentu Aleksandru z navdušenjem pozdravila združitev: »Narodna vlada SHS v Ljubljani pozdravlja z iskrenim navdušenjem ujedinjenje vseh Srbov, Hrvatov in Slovencev pod regentstvom vaše kraljeve visokosti ... Še posebno vdano zahvalo si usojamo pa sporočati za blagohotne in tolažilne obljube najodločnejše branitve celega etnografskega ozemlja SHS, zlasti tudi na naši severni in zapadni

17 Ferdo Šišić, Dokumenti o postanku Kraljevine Srba, Hrvata i Slovenaca, 1914-1919 (Zagreb: Matica Hrvatska, 1920), 277.

18 Engelsfeld, Povijest, 297.

19 Prepeluh, Pripombe, 198.

20 Več o pristojnostih in sestavi slovenske Narodne vlade v Jurij Perovšek, »Položaj Slovencev v Državi Slovencev, Hrvatov in Srbov,« Prispevki za novejšo zgodovino 59, št. 2 (2019): 45-59.

21 O razkoraku med opredeljenim ozemljem in tistim, na katerem je Narodni svet v Ljubljani dejansko izvrševal oblast, gl. Mirjam Škrk, »Profesorji Ivan Žolger, Ivan Tomšič in Stanko Peterlin ter njihovi prispevki k nastanku slovenske države,« Prispevki za novejšo zgodovino 59, št. 2 (2019): 99, 100. 
meji ... Živel jugoslovanski Trst! Živela jugoslovanska Goriška in Istra! Bog blagoslovi ujedinjeno Jugoslavijo! Bog čuvaj kralja Petra in regenta Aleksandra! «22

Navajanje Trsta, Goriške in Istre v kontekstu hvalospevov kralju in njegovemu nasledniku je izražalo slovenske upe, da bo ravno združena velika jugoslovanska država na čelu z zmagovalno dinastijo lahko preprečila italijanske posege po teh ozemljih. Kljub temu se je med Slovenci in Hrvati pojavilo kar nekaj slabe volje ob tolmačenju, po katerem so se nekdaj habsburška južnoslovanska ozemlja in na njih živeči narodi priključili Kraljevini Srbiji, ki je bila predstavljena kot osvoboditeljica s povsem naravno pravico razširitve svojega ozemlja, pod svoj zaščitniški dežnik pa bi vzela tudi Slovence in Hrvate. Takšni razlagi je nasprotovala skupina, ki je izpodbijala legalnost in legitimnost načina sprejemanja prvodecembrskega akta ter s tem utemeljevala njegovo ničnost. Teza o nelegalnosti in nelegitimnosti akta združitve je temeljila na predpostavki, da do podpisa ni prišlo po poti, ki bi jo začrtali njeni narodi ali legitimni predstavniki dveh mednarodnopravnih subjektov, temveč naj bi proces ustvarjanja Kraljestva/Kraljevine $\mathrm{SHS}^{23}$ bil rezultat delovanja nelegitimnih predstavnikov in širših mednarodnih okoliščin, ki naj bi pripomogle k vzpostavitvi srbske vizije jugoslovanstva. ${ }^{24}$ Res se je v procesu nastajanja Kraljestva SHS ignoriralo kar nekaj načel, ki so bila tedaj običajna za pogajanja $v$ mednarodnem pravu. $V$ prvi vrsti je šlo za prekoračitev pooblastil zagrebškega Narodnega sveta, ki ni zahteval mnenja niti lastnega plenuma. Tudi ob hipotetičnem izostanku državnih atributov Države SHS in posledično njene državnosti bi akt moral potrditi hrvaški sabor, ki je bil nosilec oblasti hrvaškega dela nekdaj habsburških južnoslovanskih področij in katerega subjektiviteta je bila nesporno potrjena ob razpadu habsburške monarhije. $V$ procesu združevanja s Kraljevino Srbijo je odločilen vpliv imelo tričlansko predsedstvo Osrednjega odbora zagrebškega Narodnega sveta. Za združitev pa je slednji pooblastil delegacijo, katere člani niso bili izbrani na plenarnem zasedanju, zato hrvaški pravnik Budislav Vukas ${ }^{25}$ meni, da je bil združitveni akt enostransko dejanje regenta Aleksandra, ki je ob nepooblaščenem nastopu delegatov zagrebškega Narodnega sveta potreboval ratifikacijo. Ravno zaradi njenega izostanka so predvsem hrvaški zgodovinarji združitev opisali kot nelegitimen akt, ki je bil izvršen v nasprotju s pravom, tedaj veljavnim na področju Države SHS. ${ }^{26}$ Nekoliko zmernejša opozicija je utemeljevala, da je pri nastanku Kraljestva SHS vendarle šlo za združitev dveh subjektov, ki naj bi bila enakopravna, nova država pa naj bi bila plod obojestranske volje. To stališče je torej izpodbijalo tezo o pridružitvi področja Države SHS h Kraljevini Srbiji in zagovarjalo pravno diskontinuiteto med novonastalo državo in katerim koli subjektom, ki je sodeloval pri njenem nastanku.

22 Momčilo Zečević, Slovenska ljudska stranka in jugoslovansko zedinjenje 1917-1921. Od majniške deklaracije do vidovdanske ustave (Maribor: Založba Obzorja, 1977), 182, 183.

23 1. decembra 1918 je bila ustanovljena država z nazivom Kraljestvo SHS. Z razpisom volitev v ustavodajno skupščino septembra 1920 pa se je začela imenovati Kraljevina SHS.

24 Stane Granda, Slovenija (Ljubljana: Urad vlade za komuniciranje, 2008), 198.

25 Budislav Vukas, Hrvatska državnost s gledišta međunarodnog prava (Zagreb: Pravni fakultet, 2002), 47.

26 Hrvoje Matković, Povijest Jugoslavije. Hrvatski pogled (Zagreb: Naklada Pavičić, 1998), 86. 
Nasprotnikov združitvenega akta ni bilo malo. Neuspeh katoliških grupacij pri ohranjanju meje na reki Drini, izguba pomena predvsem Zagreba pa tudi Ljubljane na račun Beograda in sprejemanje monarha iz srbske kraljevske družine so predstavljali popoln poraz pravaških gibanj in pravo katastrofo za katoliško duhovništvo Josipa Stadlerja v BIH ter za muslimansko prebivalstvo ob Drini. Resen udarec je vsaj trenutno dobila tudi slovenska katoliška politična elita, predvsem del, ki je bil še vedno lojalen Ivanu Šusteršiču. Seveda je prvodecembrski akt pomenil poraz tudi za skupine v Črni gori in Srbiji, ki so se nadejale drugačnega političnega okvira nove države. Črnogorski kralj Nikola se je po odstavitvi skupaj s privrženci zatekel po podporo $\mathrm{k}$ Italiji. Tudi socialdemokrati so postajali vse bolj radikalni, saj so bili nenaklonjeni monarhični ureditvi, ki je bila po svoji naravi antagonistična do boljševistične Rusije. Vendar so vse te opozicijske skupine pripadale različnim ideologijam, zato njihovo delovanje pogosto ni bilo usklajeno. Tudi poskusi internacionalizacije jugoslovanskega problema so ostajali na ravni iniciative posameznika ali posamezne politične stranke. Predvsem Stjepan Radić je poskušal pridobiti posluh pri kateri izmed velikih sil, po neuspehih v Londonu in Parizu pa je svojo Hrvaško kmečko stranko (najprej Hrvatska pučka seljačka stranka, od 1920 Hrvatska republikanska seljačka stranka in od 1925 Hrvatska seljačka stranka) celo včlanil v kmečko internacionalo pod okriljem Kominterne. ${ }^{27}$ Sklenemo lahko, da formiranje Kraljestva SHS ni predstavljalo le zmage jugoslovanstva, temveč je to bilo zmagoslavje specifične jugoslovanske ideje, katerega temeljni politični okvir se sicer ni v popolnosti skladal z nobeno izmed začetnih jugoslovanskih vizij, je pa glede na okvirne meje, geopolitično in upravno središče države ter najvišje državne avtoritete bil najbližje srbski ideji jugoslovanstva, ki je za temeljni cilj imela povezovanje vseh področij, poseljenih s Srbi. Številnost privržencev alternativnih rešitev postavlja $\mathrm{v}$ popolnoma drugačno luč tezo nekaterih avtorjev ${ }^{28} \mathrm{O}$ tem, da je jugoslovanstvo, kot ga je uprizorila realizirana državna ideja, bilo prisotno $\mathrm{v}$ željah večine prebivalstva pozneje nastalega Kraljestva SHS, razen kosovskih Albancev. Koncepti jugoslovanstva so si bili namreč tako različni, da je praktično nemogoče govoriti o uresničitvi želja večine prebivalstva, na kar je nakazovalo tudi neskladje med koncepti najpomembnejših političnih strank. Istočasno je dihotomizacija jugoslovanskih idej na habsburški in jugoslovanski koncept preveč poenostavljena razlaga, to pa nakazujeta razdrobljenost in neusklajeno delovanje opozicijskih struj, kar so pokazale tudi volitve v ustavodajno skupščino leta 1920.

\section{Državnost Države SHS}

Z nastankom Kraljestva SHS so bile posamezne politične skupine takoj potisnjene izven legalnega okvira in so izgubile možnost delovanja $\mathrm{v}$ strankarskem življenju.

27 Dejan Đokić, Nedostižni kompromis. Srpsko-hrvatsko pitanje u međuratnoj Jugoslaviji (Beograd: Fabrika knjiga, 2010), 83.

28 Npr. Lampe, Yugoslavia, 101. 
Ostale opozicijske politične skupine so sprejele temeljni politični okvir in so se večinoma osredotočale na proticentralistično delovanje, a tudi to jih je pogosto privedlo do roba legalnosti. $V$ tem kontekstu proticentralizacijskega političnega boja so se uporabljali številni pravni instrumenti, s pomočjo katerih se je dokazovala upravičenost spreminjanja državne ureditve. V okviru prizadevanja za večjo avtonomijo posameznih narodov, kar je veljalo za Slovensko ljudsko stranko (SLS), ali celo republik znotraj Kraljestva SHS, kar so zagovarjali v Radićevi stranki, je bilo nujno treba dokazati, da so področja, ki so iz habsburške monarhije preko Države SHS vstopila v Kraljestvo SHS, enakopravna Kraljevini Srbiji. Pri tem je šlo za poskus izpodbijanja teze o upravičeni srbski dominaciji znotraj države, ki je izvirala iz dejstva o zmagoslavju Kraljevine Srbije v vojni. Ugotavljanje pravnih razmerij med Državo SHS in Kraljevino Srbijo ter nastalim Kraljestvom SHS je predstavljalo prvovrstno politično-pravno vprašanje v obdobju po združitvi, saj je imelo številne implikacije v vseh spektrih družbenega življenja. Privrženci srbske dominacije so zagovarjali tezo o prenosu pravne subjektivitete s Kraljevine Srbije na Kraljestvo SHS, čemur je šla v prid okoliščina, da je bila srbska država zmagovalec v vojni. Na prvi pogled se je morda res zdelo, da je v vojni dveh monarhij habsburška prenehala obstajati, Karađorđevići pa so razširili oblast na nekatera ozemlja, ki so pred tem pripadala poražencu. Prav tako je bilo vnaprej jasno, da bodo nasprotniki velikosrbske doktrine nasprotovali takšnemu stališču in bodo poskušali dokazati enakopravnost ozemlja, ki je kot Država SHS vstopilo v skupno državo s Kraljevino Srbijo, posledično pa je nastal nov državni subjekt.

Pri razreševanju dileme o pravni naravi Države SHS, ki jo je tudi večina Slovencev doživela kot lastno osamosvojitev, ${ }^{29}$ je treba najprej preučiti status tega področja znotraj Avstro-Ogrske in njegov izstop iz te realne unije. Sklenemo lahko, da je Hrvaška imela poseben pravni položaj, na katerem je temeljil koncept hrvaškega državnega prava in ki ga je ohranila vse do povezovanja v južnoslovansko državo. Tudi v procesih redukcije obsega svojih pristojnosti znotraj Avstro-Ogrske je bil namreč hrvaški sabor tisti, ki je moral potrditi njihovo krnitev, zato so te prenesene pristojnosti imele značaj iure mandata, in ne iure propria. ${ }^{30} \mathrm{Ne}$ nazadnje je tudi z razkrojem habsburške monarhije hrvaški sabor sprejel pravne akte, ki so kazali na hrvaško suverenost. Najprej je s posebnim aktom prekinil državne zveze z Avstrijo in Ogrsko in je obenem reinkorporiral Hrvaško, Slavonijo in Dalmacijo, kar je nakazovalo na suverenost Hrvaške, ki je izstopila iz ene državne skupnosti in se začela povezovati v drugo. Nato je sabor sprejel odločitev o prenosu oblasti na Narodni svet Slovencev, Hrvatov in Srbov, ki je tako postal najvišji politični organ novoustanovljene Države SHS. Res je sicer, da enakega statusa slovenska in druga področja, ki niso bila v domeni hrvaškega državnega prava, niso imela. Vendar pa to ni ključno za opredeljevanje mednarodnopravne subjektivitete. Kljub temu številni avtorji omenjajo, da mora biti nastanek države v sodobnem času v skladu z mednarodnim pravom. Danes namreč originarni nastanki

29 Josip Mal, ur., Slovenci v desetletju 1918-1928 (Ljubljana: Leonova družba, 1928), II.

30 Ferdo Čulinović, Državnopravna historija jugoslavenskih zemalja XIX. i XX. stoljeća - Hrvatska, Slavonija i Dalmacija, Istra, Srpska Vojvodina, Slovenija, Bosna i Hercegovina (Zagreb: Školska knjiga, 1956), 54. 
niso več mogoči, neskladnost nastanka s pravili pa lahko povzroči nasilje. $V$ tem primeru je treba glede na obravnavano obdobje analizirati predvsem izpolnjevanje sledečih kriterijev mednarodnopravne subjektivitete: opredeljeno državno ozemlje, stalno prebivalstvo in efektivna neodvisna oblast, ki se jim pogosto dodaja še sposobnost vstopanja v odnose z drugimi državami. ${ }^{31} \mathrm{~V}$ primeru Države SHS zagrebški Narodni svet res ni eksplicitno navedel državnega teritorija, na katerem je izvrševal oblast, a je bilo ozemlje jasno določljivo iz opredelitve, da gre za vsa tista področja (habsburške monarhije), na katerih je bilo prebivalstvo večinsko južnoslovansko. Seveda se pri tem lahko zastavi vprašanje, ali je to ozemlje bilo dovolj jasno opredeljeno in ali ni že priključevanje Vojvodine k Srbiji nakazalo, da Država SHS ni imela jasno definiranih državnih mej. Vendar pa subjektiviteta države ni odvisna od nesporno določene razmejitve. Ne nazadnje tudi danes številne države, med drugimi tudi članice OZN, nimajo natančno opredeljenih meja, pa zaradi tega niso nič manj države. Ključni element, kot poudarja Ernest Petrič, ${ }^{32}$ je to, da je jedro ozemlja nesporno. Posredno je z opredelitvijo ozemlja bilo določeno tudi prebivalstvo Države SHS, ki je tudi običajno najmanj problematičen kriterij in ga izpolnjuje večina nastajajočih držav. Načelo je mogoče analogno uporabiti tudi pri izvrševanju efektivne oblasti. Res je, da zagrebški Narodni svet določenih področij nove državne tvorbe ni imel pod nadzorom, a je kljub določenim omejitvam pri izvajanju dejanske oblasti na celotnem teritoriju pokrival njegov kritični delež in vršil najpomembnejše dolžnosti. Med drugim se je tudi vključeval v mednarodne odnose po Jugoslovanskem odboru. ${ }^{33}$ Argument, ki ga je velikosrbska doktrina najbolj poudarjala pri zavračanju obstoja državnosti Državi SHS in utemeljevanju Kraljevine Srbije kot edinega subjekta z mednarodnopravno subjektiviteto, je bil izostanek mednarodnega priznanja Države SHS kljub prizadevanjem zagrebškega Narodnega sveta. ${ }^{34}$ Vendar tej tezi nasprotuje dejstvo, da so določeni mednarodni odnosi Države SHS z ostalimi državami obstajali, kar kaže na t.i. »tiho « ali posredno priznanje. Vukas ${ }^{35}$ kot primer navaja, da so v novembru leta 1918 državne oblasti (zagrebški Narodni svet) prejele več diplomatskih notifikacij, celo obvestila o postavljanju tujih diplomatskih predstavnikov. Kot posredni dokaz priznavanja subjektivitete Državi SHS pa lahko razumemo tudi enakopravno sodelovanje njenih predstavnikov na konferenci v Ženevi od 6. do 9. novembra 1918, kar neposredno kaže na to, da je Država SHS imela sposobnost vzpostaviti enakopravne odnose z drugimi državami. Slednje pa je tudi najboljši dokaz, da je bila ta država sposobna stopati v razmerja z ostalimi državami. Sicer pa mednarodno priznanje le utrjuje mednarodni položaj subjekta, ni pa konstitutivni element državnosti. ${ }^{36}$ To stališče je potrdila tudi Montevidejska konvencija o pravicah in dolžnostih držav, ki je leta 1933 državo opredelila kot »skupnost določenega ozemlja, prebivalstva na tem ozemlju, suverene in

31 James Crawford, The Creation of States in International Law (Oxford: Clarendon, 2007), 111-19.

32 Ernest Petrič, Zunanja politika: osnove teorije in praksa (Mengeš: Center za evropsko prihodnost, 2010), 190.

33 Vukas, Hrvatska državnost, 45.

34 Več o aktivnostih Narodnega sveta v Perovšek, Slovenski prevrat 1918, 106.

35 Vukas, Hrvatska državnost, 45.

36 Engelsfeld, Povijest, 290. 
efektivne oblasti nad prebivalstvom na tem ozemlju in sposobnosti vzpostaviti odnose z drugimi državami $\ll{ }^{37}$ To govori v prid tezi o državnosti Države SHS, ${ }^{38}$ ki so jo ne nazadnje implicitno priznavali tudi nekateri tedanji srbski ustavni pravniki. Slobodan Jovanović ${ }^{39}$ je na primer že leta 1924 trdil, da se je hrvaški parlament ali sabor svojevoljno odločil prenesti svoja pooblastila na zagrebški Narodni svet, s čimer se je odrekel vrhovni oblasti in ukinil neodvisno hrvaško državo $\mathrm{v}$ prid novoustanovljeni Državi SHS.

\section{Vprašanje kontinuitete med Kraljevino Srbijo in Kraljestvom SHS}

Bistveno več razprav kot dilema o državnosti Države SHS je v tedanje politično življenje vnesel spor glede ugotavljanja odnosa med Kraljevino Srbijo in Kraljestvom/ Kraljevino SHS. Če bi namreč obveljala teza o pravni kontinuiteti slednjih, bi to impliciralo, da je Kraljestvo/Kraljevina SHS pravni naslednik Kraljevine Srbije, medtem ko bi področja in narodi Države SHS predstavljali anektiran dodatek, ki si ga je Srbija priborila z zmago v vojni. Zanimivo je, da je to vprašanje prva poudarila Nemčija, ki je sprožila spor glede likvidacije nemške lastnine na področju Kraljevine SHS. Pri tem je zagovarjala stališče, da Kraljevina SHS kot nova država nima enakih pravic, ki so jih po Versajskem mirovnem sporazumu imele ostale zavezniške države. Sporazum je namreč povojne države razdelil na »nove « in »stare «, kar je imelo pomembne ekonomske posledice. Nemčija je bila tako dolžna povrniti škodo samo civilnemu prebivalstvu iz držav zavezniških antantnih sil in prebivalstvu antanti pridruženih držav. ${ }^{40}$ Enega izmed načinov povrnitve škode je predstavljal prenos nemške lastnine v teh državah na države zmagovalke v prvi svetovni vojni ${ }^{41}$ Izjema je veljala za nove države, ki niso imele pravnega naslova niti »cause «, da bi lahko izvedle likvidacijo, saj v času izvrševanja škodnih dejanj niso obstajale. Kljub temu so si tudi nekatere izmed teh držav po vojni prisvojile nemško lastnino, zato je 297. člen Versajskega sporazuma omogočal vračanje te lastnine ali nadomestilo škode njenim lastnikom. Nemčija je to pravico lahko uveljavljala s pomočjo »ad hoc « ustanovljenih mešanih sodišč, kar se je zgodilo tudi pri nemški tožbi proti Kraljevini SHS. Ustanovljeno mešano sodišče je najprej moralo odločiti o predhodnem vprašanju, ali je Kraljestvo/Kraljevina SHS nova ali stara država, pri čemer je tribunal nekoliko presenetljivo ugotovil, da gre $\mathrm{v}$ tem primeru za »staro « državo. To je seveda šlo v prid velikosrbski doktrini, saj naj bi sodba potrdila,

37 Petrič, Zunanja politika, 184.

38 Jurij Perovšek, »Nastanek Države Slovencev, Hrvatov in Srbov 29. oktobra in njen zgodovinski pomen,« Studia Historica Slovenica 19, št. 2 (2019): 370.

39 Slobodan Jovanović, Ustavno pravo Kraljevine Srba, Hrvata i Slovenaca (Beograd: Službeni list SRJ, 1995), 34.

40 Treaty of Peace with Austria (St. Germain-en-Laye, 10. september 1919), 177. in 178. člen, dostopno na: http:// www.austlii.edu.au/au/other/dfat/treaties/1920/3.html.

41 The Peace Treaty of Versailles (28. junij 1919), 243. in 297. člen, dostopno na: http://net.lib.byu.edu/ rdh7/wwi/ versailles.html. 
da je Kraljestvo/Kraljevina SHS pravna naslednica Kraljevine Srbije. Slednja naj bi po takšni razlagi dobila le novo ime, Kraljestvo/Kraljevina SHS pa je potemtakem pravzaprav le povečana Kraljevina Srbija. To ugotovitev sodišča je zadovoljno komentiral tedaj vodilni srbski pravnik Dušan Subotić, ki je bil tudi sam član tega sodišča. Pri tem je poudaril, da naj bi sodišče pravno kontinuiteto Kraljestva/Kraljevine SHS obravnavalo z mednarodnopravnega vidika, zato je tudi mednarodnopravna subjektiviteta Kraljestva/Kraljevine SHS izhajala iz subjektivitete Kraljevine Srbije. ${ }^{42}$ Temu je sledil odgovor Ivana Žolgerja, sicer uglednega pravnika in diplomata, člana jugoslovanskega dela komisij, ${ }^{43}$ ki sta odločali o povojnih mejah z Avstrijo in Madžarsko. ${ }^{44}$ Žolger je v članku z naslovom »Da li je naša Kraljevina nova ili stara država? « ugotovitev o kontinuiteti srbske države analiziral s stališča tedanjih mednarodnopravnih določb in tudi pristojnosti omenjenega sodišča, da izreka pravnomočne sodbe o pravni naravi držav. Najprej je poudaril dejstvo, da je »novost « države formalne narave, medtem ko je pravica do likvidacije nemškega premoženja izhajala iz materialnih dejstev, in sicer obstoja civilnega prebivalstva, ki je na takšen ali drugačen način ( $z$ nezakonitim izvajanjem sovražnosti ali izrednih odredb proti lastnini) oškodovano z nemškimi postopki. ${ }^{45}$ Obenem je po mnenju Žolgerja sodišče novost države presojalo, čeprav je to bilo izven njegove pristojnosti. V skladu z 297. členom Versajskega sporazuma Kraljestvo/Kraljevina SHS ni bila nova država, saj je imela civilno prebivalstvo, ki ga je Nemčija oškodovala v vojni. Zato je tudi Žolger mnenil, da je nemška tožba neutemeljena, a je poenostavljeno interpretacijo sodišča izpodbijal. Sodišče se je namreč sklicevalo na t. i. »valutne fakte «. Saintgermainski in Trianonski sporazum sta pri določanju višine reparacij opredeljevala valutno razmerje med državo plačnico in državo prejemnico, pri čemer naj bi veljal menjalni tečaj, ki je obstajal dva meseca pred razpadom Avstro-Ogrske po ženevskem tečaju. $\mathrm{V}$ tem kontekstu sta bili Poljska in Češkoslovaška obravnavani kot novi državi, saj med vojno še nista imeli svojih valut. ${ }^{46}$ Analogno je bilo dejstvo, da je dinar veljal kot valuta v Kraljevini Srbiji in nato po vojni tudi v Kraljestvu/Kraljevini SHS, odločilno, da je sodišče to državo opredelilo kot staro. Če z današnjega vidika s pravno logiko upoštevamo tedaj veljavna mednarodna načela, lahko ugotovimo, da je bilo Žolgerjevo mnenje vsekakor bolj utemeljeno in pravno konsistentno. Obstoj mednarodno priznane valute za Kraljestvo/Kraljevino SHS ni bil niti nujen, še manj pa zadosten kriterij, da bi državo lahko opredelili kot staro. Hipotetično bi se namreč lahko neka država odrekla svoji monetarni suverenosti in sprejela denarno valuto druge države, a to še ne pomeni, da se je odrekla svoji mednarodni subjektiviteti. Tudi v obravnavanem primeru je bil en sam atribut, ki je Kraljestvo/Kraljevino SHS ločil od Poljske in Češkoslovaške, prešibek za tako močan sklep. Mirovne sporazume je

42 Škrk, »Profesorji, 103.

43 O vlogi Ivana Žolgerja v delu v komisijah gl. Andrej Rahten, $\gg$ Slovenski pravniki na diplomatskem parketu do mednarodnega priznanja nove države, « Prispevki za noveǰ̌o zgodovino 59, št. 2 (2019): 115-29.

44 Bogdan Krizman, Vanjska politika jugoslavenske države 1918-1941. Diplomatsko-historijski pregled (Zagreb: Školska knjiga, 1975), 20.

45 Ivan Žolger, »Da li je naša kraljevina nova ili stara država?,« Slovenski pravnik 37, št. 3-4 (1923): 7.

46 Treaty of Peace with Austria, 248. člen. 
namreč treba tolmačiti v skladu s poslanstvom njihovega obstoja, saj večinoma odrejajo le posamezne pravice in dolžnosti držav, njihovo subjektiviteto pa predpostavljajo in se ne spuščajo v pravno analizo njihovega nastanka. Tako je tudi Saintgermainski sporazum v preambuli le ugotovil, da je Avstro-Ogrska prenehala obstajati; da sta nastali češkoslovaška in jugoslovanska država; obe državi sta mednarodno priznani. Poslanstvo sporazuma je bilo urejanje položaja med antantnimi zaveznicami in poraženimi državami, nikakor pa sporazum ni posegal v akte že izvršene ustanovitve novih držav niti jih ni imel namena preučevati.

Ključni Žolgerjev kriterij za določanje novosti države je bila ustava. Po njegovem tolmačenju ustavni akt nove države določa (dis)kontinuiteto sedanje države s prejšnjo. Država je potemtakem stara, le če je razvidno opiranje sedanje ustave na prejšnjo. ${ }^{47}$ Po istem avtorju ni bilo nobenega dvoma, da začasni ustavni akt Kraljestva SHS ni bil ustvarjen po normah ustave Kraljevine Srbije iz leta 1903, kar implicira prekinitev kontinuitete prejšnje srbske države. Proces sprejemanja začasne ustave namreč ni bil v skladu z določbami srbske ustave in njenega 200. člena, ki je določal edine mogoče postopke ustavnih sprememb. Posledično je pri ustanovitvi Kraljestva SHS šlo za sporazumni prelom ustavnega reda Kraljevine Srbije. Sporazum glede te prekinitve je imel temelj v mednarodnem dogovoru, ki ni potekal po pravilih srbske ustave, saj ga ni potrdil srbski parlament, kot je to določal 52. člen prejšnje srbske ustave. ${ }^{48}$ Tudi vlada Kraljestva SHS se je sestavila povsem v nasprotju z določbami te ustave in je svojo legitimnost utemeljevala na mednarodnem sporazumu, čeprav ta ni bil ratificiran pred predstavniškim telesom katere koli izmed sporazumnih strani. Bistveni argument za pravno diskontinuiteto med Kraljevino Srbijo in Kraljestvom/Kraljevino SHS se je torej skrival $\mathrm{v}$ tem mednarodnem aktu, katerega bistvo je bila odredba o ustvarjanju nove ustave, to pa je določil na način, ki ga srbska ustava ni priznavala niti ga ni poznalo tedanje mednarodno pravo. $\mathrm{V}$ tem primeru namreč ni prišlo do cesije, debelacije, okupacije ali akcesije, ki so bili edini štirje primeri, ki naj bi jih po Žolgerjevem mnenju običajno pravo priznavalo, ko gre za povečanje ali širitev države. ${ }^{49}$ Ravno nasprotno, Kraljevina Srbija je sklenila sporazum s predstavniki Države SHS, s čimer je priznala njeno enakopravnost, kar tudi nakazuje na akt združitve, ki je poleg razpada, odcepitve in dekolonizacije oblika derivativnega nastanka države. ${ }^{50} \mathrm{Na}$ podlagi tega lahko sklepamo, da je zagrebški Narodni svet (na področju Države SHS) imel enake pristojnosti, kot so jih imeli najvišji instituti oblasti v Kraljevini Srbiji. To izhaja tudi iz akta zagrebškega Narodnega sveta s 3. decembra 1918, s katerim je opustil izvajanje oblasti in to prenesel na srbskega regenta. Država SHS torej ni vstopila v Kraljevino Srbijo, temveč je s slednjo ustanovila novo državo, kar so v svojih zapisih ne nazadnje potrjevali tudi nekateri privrženci unitaristične ideje. Milan Pribićević, Svetozarjev brat, je na primer v svojem pismu Seatonu Watsonu pisal, da gre za »združenje južnoslovanskih držav«,

47 Žolger, »Da li je naša kraljevina, « 11 .

48 Ustav za Kraljevinu Srbiju (Beograd: Državna štamparija Kraljevine Srbije, 1903), 52. člen.

49 Žolger, $\gg$ Da li je naša kraljevina, $\ll 13$.

50 Danilo Türk, Temelji mednarodnega prava (Ljubljana: GV Založba, 2007), 89. 
iz česar je bila razvidna percepcija Države SHS kot države, ki se je združila s Kraljevino Srbijo. ${ }^{51}$ Združevanje implicira dejstvo nastanka novega subjekta in posledično prenehanja obstoja dveh prejšnjih subjektov, česar ne izpodbija niti dejstvo, da je dinastija Karađorđević zadržala svojo funkcijo tudi v novi državi. Tudi položaj kraljeve družine je bil namreč utemeljen s predmetno mednarodno pogodbo, enako pa je veljalo tudi za zakonodajno in izvršno oblast, državno ozemlje in narod. Poleg tega tudi novo ime in novi simboli kažejo na državnopravno ločevanje Kraljevine Srbije in Kraljestva/ Kraljevine SHS.

Iz opredeljenega izhaja, da je Subotić odnos med mednarodnim in notranjim pravom razumel po dualističnem načelu. Le s tem lahko pojasnimo trditev, da je država lahko obenem stara po mednarodnem pravu in nova po notranjem pravu. V skladu $s$ tem je Subotić menil, da gre pri Kraljestvu/Kraljevini SHS za nov ustavni red in posledično novo notranjo ureditev, istočasno pa naj bi ta država podedovala mednarodni položaj Kraljevine Srbije. Žolger je dualistično teorijo imel za nesmiselno, saj je onemogočala relevantno presojanje nastanka države. Sam je zavzemal stališče monistične paradigme, po kateri mednarodnopravne narave subjekta ni mogoče presojati ločeno od notranjepravnega razumevanja nastanka države. $V$ povezavi s tem se $\mathrm{v}$ mednarodnopravnih zadevah pri presojanju ene zadeve ne more uporabiti predhodna odločitev iz nekega drugega procesa, katerega primarni namen ni reševanje tega vprašanja. Ravno zato omenjena valutna klavzula ni mogla biti relevantna za opredelitev mednarodnopravnega položaja Kraljestva/Kraljevine SHS, saj valuta ni stvar, ki določa državno bistvo. Nekonsistentnost presojanja kontinuitete države z opiranjem na posamezne mednarodnopravne akte, ki se ne ukvarjajo z bistvom države, je Žolger podkrepil s primerom pogodbe med Kraljestvom SHS in t. i. Glavnimi silami iz leta 1919. Ta je potrdila, da so Srbi, Hrvati in Slovenci iz bivše avstro-ogrske monarhije z lastno voljo sklenili združiti se s Srbijo z namero ustvarjanja ene neodvisne in združene države z imenom Kraljevina Srbov, Hrvatov in Slovencev, ki je prevzela suverenost na ozemlju, na katerem ti narodi živijo. ${ }^{52} \mathrm{Na}$ nekdanja avstro-ogrska področja torej Srbija ni razširila svoje suverenosti, saj so Slovenci, Hrvati in Srbi s teh področij samostojno prenesli svojo suverenost na novonastalo državo, kar implicira novo originarno suverenost. Indikativno je, da so to potrjevali tudi predstavniki liberalnega slovenskega političnega kroga, ki so sicer favorizirali zedinjenje s Srbijo, saj naj bi jim to omogočilo ugodnejše pogoje $v$ tekmi s slovenskim katoliškim političnim polom, ${ }^{53}$ pri čemer so se naslanjali na politično strategijo Svetozarja Pribičevića. ${ }^{54}$ Tako je na primer Ivan Tavčar že 6. julija 1919 na zboru zaupnikov Jugoslovanske demokratske stranke (JDS) izjavil, da želijo biti »neomahljivi služabniki $(. .$.$) novi državi «. { }^{55}$

51 Đokić, Nedostižni kompromis, 65.

52 Žolger, $\gg$ Da li je naša kraljevina, « 16.

53 Jurij Perovšek, Liberalizem in vprašanje slovenstva (Ljubljana: Modrijan, 1996), 112.

54 Momčilo Zečević, Na zgodovinski prelomnici (Maribor: Založba Obzorja, 1986), 89.

55 Perovšek, Liberalizem, 142. 


\section{Sklep}

Obravnavo dveh ključnih državnopravnih vprašanj pri južnih Slovanih ob koncu prve svetovne vojne otežuje dejstvo, da v tistem času mednarodno pravo še ni poznalo vseh sodobnih pravnih instrumentov. Ne glede na to lahko sklenemo, da so pravni argumenti vendarle potrdili obstoj državnosti Države SHS, ki je kljub kratkotrajnosti zadovoljevala bistvene kriterije mednarodne subjektivitete. Slednja je nastala na delu ozemlja Avstro-Ogrske, ki je s koncem prve svetovne vojne razpadla, kar je eno od izhodišč za derivativni nastanek držav. Volja prebivalstva, na temelju katere lahko sklepamo o samoodločbi, je bila razvidna iz aktov tedaj obstoječih voljenih, torej legitimnih predstavniških organov (npr. hrvaškega sabora). Res je sicer izostalo formalno mednarodno priznanje, ki pa po deklarativni teoriji ni konstitutivni element državnosti. Država SHS je izpolnjevala vse temeljne kriterije, ki so bili pozneje tudi formalno potrjeni v Montevidejski konvenciji, stalno prebivalstvo, ozemlje in efektivno oblast. Istočasno je država imela tudi sposobnost vzpostavljanja odnosov z drugimi subjekti mednarodnega prava. ${ }^{56}$ Ravno tako drži, da v mednarodnem pravu še vedno obstaja tudi veja, ki zagovarja nujnost mednarodnega priznanja, a je tudi to na določen način v kratkem obdobju življenja Države SHS izkazano implicitno, s stopanjem v odnose z drugimi mednarodnimi subjekti.

Analiza prvodecembrskega akta nas navaja na zaključek, da je pri procesu združevanja šlo za prekoračitev pooblastil zagrebškega Narodnega sveta, saj ta ni zahteval mnenja lastnega plenuma, temveč je večino odločitev sprejemalo tričlansko predsedstvo osrednjega odbora. Tudi pri aktu združitve je zagrebški Narodni svet pooblastil 28 članov, ki niso bili izbrani na plenarnem zasedanju. Poleg tega je delegacija, ki je odšla v Beograd, prezrla zavezujoča navodila, podpisani prvodecembrski akt pa ni dobil potrebne ratifikacije, kar bi bilo v skladu s tedaj veljavno ureditvijo. Ravno ta pravni moment je zagotovo eden ključnih dejavnikov, ki nas vodi do sklepa, da je Kraljestvo/ Kraljevina SHS vendarle bila nova država, saj je imela novo ustavo, ki je prekinila kontinuiteto prejšnje srbske ustave. Začasna ureditev, ki jo je Kraljestvo SHS dobilo 1. decembra 1918, namreč ni bila ustvarjena po normah določb srbske ustave iz leta 1903, temveč je bila posledica sporazumnega preloma ustavnega reda Kraljevine Srbije, do katerega je prišlo $\mathrm{z}$ mednarodnim dogovorom med dvema formalno enakopravnima subjektoma. Izvršna oblast, vlada nove države, je svojo legitimnost utemeljevala na mednarodnem sporazumu. Kljub formalni enakopravnosti dejanski pogajalski izhodišči Kraljevine Srbije in Države SHS še zdaleč nista bili enaki, različni pa so bili tudi načini političnega delovanja, kar se je izkazalo $v$ parlamentarnih razpravah o ureditvi države. ${ }^{57}$ To je potrdila tudi Vidovdanska ustava, ki je predstavljala potrditev predloga

56 Montevidejska konvencija (26. 12. 1933), 1. člen, dostopno na: http://www.cfr.org/sovereignty/montevideo-convention-rights-duties-states/p15897.

57 Jure Gašparič, »Parlamentarna razprava v prvi Jugoslaviji, « Prispevki za novejšo zgodovino 54, št. 2 (2014): 63-78. 
pretežno srbskih oblasti, ${ }^{58} \mathrm{ki} \mathrm{je}$, kot je to zapisal Christian Nielsen, ${ }^{59} \mathrm{z}$ dnevom sprejetja poslala sporočilo, da je $\mathrm{v}$ državi prevladala srbska nacionalna ideologija. Vendar to ni dovolj, da bi se lahko strinjali s tezo nekaterih pravnikov, ${ }^{60}$ da je pri nastanku nove države šlo za priključitev Države SHS h Kraljevini Srbiji. Dejstvo pa je, da so izkazana notranja neskladja, katerih del prikazuje tudi spor glede pravne narave Države SHS in Kraljestva/Kraljevine SHS, izčrpavala novo državo in vplivala na njeno notranjo nestabilnost ${ }^{61}$ ter tako še povečevala možnost zunanjega vpliva na njeno oblikovanje.

\section{Viri in literatura}

- Banac, Ivo. Nacionalno pitanje u Jugoslaviji. Porijeklo, povijest, politika. Zagreb: Globus, 1988.

- Banac, Ivo. »Emperor Karl Has Become a Comitadji: The Croatian Disturbances of Autumn 1918. « The Slavonic and East European Review 70, št. 2 (1992): 284-305.

- Crawford, James. The Creation of States in International Law. Oxford: Clarendon, 2007.

- Čulinović, Ferdo. Državnopravna historija jugoslavenskih zemalja XIX. i XX. stoljeća - Hrvatska, Slavonija i Dalmacija, Istra, Srpska Vojvodina, Slovenija, bosna i Hercegovina. Zagreb: Školska knjiga, 1956.

- Čulinović, Ferdo. Jugoslavija izmedu dva rata. Zagreb: Jugoslavenska akademija znanosti i umjetnosti, 1961.

- Čulinović, Ferdo. Tri etape nacionalnog pitanja u jugoslovenskim zemljama. Zagreb: Jugoslavenska akademija znanosti i umjetnosti, 1962.

- Đokić, Dejan. Nedostižni kompromis. Srpsko-hrvatsko pitanje u međuratnoj Jugoslaviji. Beograd: Fabrika knjiga, 2010.

- Engelsfeld, Neda. Povijest hrvatske države i prava - razdoblje od 18. do 20. stoljeća. Zagreb: Pravni fakultet, 2002.

- Gašparič, Jure. »Parlamentarna razprava v prvi Jugoslaviji.«Prispevki za novejšo zgodovino 54, št. 2 (2014): 63-78.

- Granda, Stane. Slovenija. Ljubljana: Urad vlade za komuniciranje, 2008.

- Jovanović, Slobodan. Ustavno pravo Kraljevine Srba, Hrvata i Slovenaca. Beograd: Službeni list SRJ, 1995.

- Krizman, Bogdan. Vanjska politika jugoslavenske države 1918-1941. Diplomatsko-historijski pregled. Zagreb: Školska knjiga, 1975.

- Lampe, John R. Yugoslavia as History. Twice There Was a Country. Second edition. Cambridge: Cambrige University press, 2002.

- Lavrič, Jože, Josip Mal in Franc Stele, ur. Spominski zbornik Slovenije. Ljubljana: Jubilej, 1939.

- Lukan, Walter. Iz »črnožolte kletke narodov « $v$ »zlato svobodo «? Habsburška monarhija in Slovenci v prvi svetovni vojni. Ljubljana: Znanstvena založba Filozofske fakultete Univerze v Ljubljani, 2014.

- Mal, Josip, ur. Slovenci v desetletju 1918-1928. Ljubljana: Leonova družba, 1928.

- Matković, Hrvoje. Povijest Jugoslavije. Hrvatski pogled. Zagreb: Naklada Pavičić, 1998.

- Montevidejska konvencija, 26. 12. 1933. Dostopno na: http://www.cfr.org/sovereignty/montevideo-convention-rights-duties-states/p15897.

- Nielsen, Christian. A. Making Yugoslavs. Identity in King Aleksandar's Yugoslavia. Toronto: University of Toronto Press, 2014.

58 Ferdo Čulinović, Jugoslavija između dva rata (Zagreb: Jugoslavenska akademija znanosti i umjetnosti, 1961), 219.

59 Christian A. Nielsen, Making Yugoslavs. Identity in King Aleksandar's Yugoslavia (Toronto: University of Toronto Press, 2014), 40.

60 Npr. Ciril Ribičič, Ustavnopravni vidiki osamosvajanja Slovenije (Ljubljana: Časopisni zavod Uradni list Republike Slovenije, 1992), 6.

61 Nielsen, Making Yugoslavs, 41. 
- Perovšek, Jurij. Liberalizem in vprašanje slovenstva. Ljubljana: Modrijan, 1996.

- Perovšek, Jurij. Slovenska osamosvojitev v letu 1918. Ljubljana: Modrijan, 1998.

- Perovšek, Jurij. »Jugoslovanska združitev.« V: Slovenska novejša zgodovina. Od programa Zedinjena Slovenija do mednarodnega priznanja Republike Slovenije: 1848-1992, ur. Jasna Fisher et al., 200-03. Ljubljana: Mladinska knjiga in Inštitut za novejšo zgodovino, 2005.

- Perovšek, Jurij. Slovenski prevrat 1918. Položaj Slovencev v Državi Slovencev, Hrvatov in Srbov. Ljubljana: Inštitut za novejšo zgodovino, 2018.

- Perovšek, Jurij. »Nastanek Države Slovencev, Hrvatov in Srbov 29. oktobra in njen zgodovinski pomen.« Studia Historica Slovenica 19, št. 2 (2019): 369-98.

- Perovšek, Jurij. »Položaj Slovencev v Državi Slovencev, Hrvatov in Srbov.« Prispevki za novejšo zgodovino 59, št. 2 (2019): 40-74.

- Petrič, Ernest. Zunanja politika: osnove teorije in praksa. Mengeš: Center za evropsko prihodnost, 2010.

- Pleterski, Janko. Prva odločitev Slovencev za Jugoslavijo. Ljubljana: Slovenska matica, 1971.

- Prepeluh, Albin. Pripombe k naši prevratni dobi. Trst: Založništvo tržaškega tiska, 1987.

- Radić, Stjepan. Politički spisi: Autobiografija, članci, govori, rasprave. Zagreb: Znanje, 1971.

- Rahten, Andrej. Slovenska ljudska stranka v beograjski skupščini. Jugoslovanski klub v parlamentarnem

- življenju Kraljevine SHS 1919-1929. Ljubljana: Založba ZRC, 2002.

- Rahten, Andrej. »Slovenski pravniki na diplomatskem parketu do mednarodnega priznanja nove države.« Prispevki za novejšo zgodovino 59, št. 2 (2019): 115-29.

- Ribičič, Ciril. Ustavnopravni vidiki osamosvajanja Slovenije. Ljubljana: Časopisni zavod Uradni list Republike Slovenije, 1992.

- Stavbar, Vlasta. Majniška deklaracija in deklaracijsko gibanje. Maribor: Založba Pivec, 2017.

- Šišić, Ferdo. Dokumenti o postanku Kraljevine Srba, Hrvata i Slovenaca, 1914-1919. Zagreb: Matica Hrvatska, 1920.

- Škrk, Mirjam. »Profesorji Ivan Žolger, Ivan Tomšič in Stanko Peterlin ter njihovi prispevki k nastanku slovenske države.«Prispevki za novejšo zgodovino 59, št. 2 (2019): 95-114.

- The Peace Treaty of Versailles, 28. 6. 1919. Dostopno na: http://net.lib.byu.edu/ rdh7/wwi/versailles.html.

- Treaty of Peace with Austria. St. Germain-en-Laye, 10 September 1919. Dostopno na: http://www. austlii.edu.au/au/other/dfat/treaties/1920/3.html.

- Türk, Danilo. Temelji mednarodnega prava. Ljubljana: GV Založba, 2007.

- Ustav za Kraljevinu Srbiju. Beograd: Državna štamparija Kraljevine Srbije, 1903.

- Vukas, Budislav. Hrvatska državnost s gledišta medunarodnog prava. Zagreb: Pravni fakultet, 2002.

- Zečević, Momčilo. Slovenska ljudska stranka in jugoslovansko zedinjenje 1917-1921: Od majniške deklaracije do vidovdanske ustave. Maribor: Založba Obzorja, 1977.

- Zečević, Momčilo. Na zgodovinski prelomnici. Maribor: Založba Obzorja, 1986.

- Žolger, Ivan. »Da li je naša kraljevina nova ili stara država?.« Slovenski pravnik, št. 3-4 (1923): $1-18$. 


\section{Igor Ivašković}

\section{THE LEGAL NATURE OF THE STATE AND THE KINGDOM OF SHS IN THE CONTEXT OF THE CONFLICTING YUGOSLAV IDEOLOGIES}

\section{SUMMARY}

The contribution analyses the discrepancy between the interpretations of the two key state-legal questions regarding the South Slavs after the end of World War I: the dilemma about the legal nature of the State of Slovenes, Croats and Serbs and the dispute regarding the legal (dis)continuity between the Kingdom of Serbia and the Kingdom of Serbs, Croats and Slovenes. It is a fact that at the time, international law did not yet possess all of the modern legal instruments. However, the use of the contemporaneous as well as subsequently developed international and constitutional criteria nevertheless implies a conclusion about the existence of the statehood of the State of SHS, which, despite its brief existence, still satisfied the essential criteria of international subjectivity. The State of SHS was established in the part of the territory of Austria-Hungary, which dissolved at the end of World War I. This represented one of the foundations for the derivative creation of states. The will of the population, based on which we can draw conclusions regarding self-determination, was evident from the legal acts of the contemporaneous elected and thus legitimate representative bodies. There was indeed no formal international recognition, yet according to the declarative theory, that is not a constitutive element of statehood. The State of SHS fulfilled all of the fundamental criteria that would later be also formally confirmed by the Montevideo Convention: a permanent population, defined territory, and effective government, which nevertheless did not encompass all the areas of the former AustriaHungary defined by the executive authorities. At the same time, the state had the capacity to enter into relations with other subjects of international law, which implied the recognition of the State of SHS by certain other such subjects. In the second part, the contribution analyses the various interpretations of the December 1 Act that proclaimed the establishment of the Kingdom of Serbs, Croats and Slovenes. The analysis of this Act leads to the conclusion that the process of unification exceeded the powers of the Central Committee of the National Council in Zagreb as well as of the delegation appointed for the realisation of the act of unification. Primarily, most of the decisions within the National Council in Zagreb were made by the three-member presidency of the Central Committee, while the very act of unification appointed 28 members that had not been selected at a plenary meeting. The delegation that went to Belgrade also overlooked the binding instructions, while the signed December 1 Act was also not ratified as necessary, which would have been in accordance with the contemporaneous system. This very legal moment undoubtedly represents one of the key factors leading to the conclusion that the Kingdom of SHS was nevertheless a new state, as it had a 
new constitution that broke the continuity of the former Serbian Constitution. The temporary system introduced in the Kingdom of SHS on 1 December 1918 did not adhere to the norms of the 1903 Serbian Constitution. Instead, it was a consequence of a consensual rupture with the constitutional order of the Kingdom of Serbia, which resulted from an international agreement between two formally equal subjects. The executive authority - the government of the new state - based its legitimacy on the international agreement as well. However, despite the formal equality, the actual negotiating positions of the Kingdom of Serbia and the State of SHS were nowhere near equal. This was also confirmed by the subsequent St Vitus' Day Constitution, which represented the confirmation of the proposals made by the predominantly Serbian authorities. Nevertheless, this fact is not enough to confirm the thesis of certain lawyers, claiming that the case of the creation of the new state involved an annexation of the State of SHS to the Kingdom of Serbia. We can, however, agree with the argumentation in favour of the thesis that the differences in the explanation of the legal nature of the State of Slovenes, Croats and Serbs - as well as that of the Kingdom of Serbs, Croats and Slovenes - did not result from legal uncertainty to the degree that they represented a reflection of yet another of the many political struggles in the conflict between the opposing Yugoslav ideologies. 